\title{
Polar stratification: A critical view from the Southern Ocean
}

\author{
Claus-Dieter Hillenbrand $^{\mathrm{a}, *}$, Giuseppe Cortese $^{\mathrm{b}}$ \\ a British Antarctic Survey, High Cross, Madingley Road, Cambridge CB3 OET, UK \\ b Alfred Wegener Institute for Polar and Marine Research, Columbusstrasse, D-27568 Bremerhaven, Germany
}

Received 15 February 2006; received in revised form 26 May 2006; accepted 7 June 2006

\begin{abstract}
Oceanic stratification represents an effective mechanism to reduce vertical mixing of the water column, thereby locking up carbon dioxide $\left(\mathrm{CO}_{2}\right)$ in the deep sea and preventing air-sea exchange of $\mathrm{CO}_{2}$. It has been proposed that enhanced stratification of the upper water column in polar oceans during late Cenozoic cooling episodes limited the upwelling of $\mathrm{CO}_{2}$-rich deep waters and thus $\mathrm{CO}_{2}$-release to the atmosphere, resulting in a net global drawdown of atmospheric $\mathrm{CO}_{2}$. Increased stratification in the Subarctic Northwest Pacific, during both the onset of Northern Hemisphere glaciation at 2.73 Ma and late Quaternary glacial periods, has been recently linked to enhanced ocean stratification south of the Antarctic Polar Front (APF) in the Pacific and Atlantic sectors of the Southern Ocean. Increased stratification of Southern Ocean surface waters was mainly deduced from a reduction of biological production during these cooling episodes, manifested by the decrease of geochemical proxies for productivity, such as biogenic opal and barium, in the marine sediment records. However, the records chosen from the Southern Ocean do not provide evidence for a more stratified upper water column, rather the observed decrease in biological productivity is likely to have resulted from an expansion of annual sea-ice coverage. The sediment records suggest that south of the APF in the Pacific and Atlantic sectors of the Southern Ocean, extensive sea ice may have contributed to the global $\mathrm{CO}_{2}$-drawdown during glacial periods, with hypothetical glacial increase of stratification in today's permanent open-ocean zone merely being an "add on" caused by this expansion.
\end{abstract}

(C) 2006 Elsevier B.V. All rights reserved.

Keywords: Palaeoproductivity; Palaeoclimate; Sea ice; Southern Ocean; Stratification

\section{Introduction}

Over the last decade biological, chemical and physical processes in the Southern Ocean have been suggested to play an important role in controlling atmospheric carbon dioxide $\left(\mathrm{CO}_{2}\right)$ concentrations and thus global climate changes during the late Neogene and Quaternary (e.g. Kumar et al., 1995; Francois et al., 1997; Elderfield and

\footnotetext{
* Corresponding author. Tel.: +44 1223 221340; fax: +44 1223 221646.

E-mail address: hilc@bas.ac.uk (C.-D. Hillenbrand).
}

Rickaby, 2000; Frank et al., 2000; Moore et al., 2000; Sigman and Boyle, 2000; Stephens and Keeling, 2000; Schneider-Mor et al., 2005; Abelmann et al., 2006). By means of physico-chemical mechanisms, in particular two competing hypotheses have emerged, which attempt to explain the global atmospheric $\mathrm{CO}_{2}$-reduction of 80 100 ppm during late Quaternary glacial periods. Both ideas propose that today's region south of the Antarctic Polar Front (APF), i.e. the seasonally sea-ice covered zone (SIZ) and the permanent open-ocean zone (POOZ) (e.g. Pondaven et al., 2000), acted as a $\mathrm{CO}_{2}$ source during preindustrial interglacial periods as a result of $\mathrm{CO}_{2}$-release to 
the atmosphere due to the upwelling of $\mathrm{CO}_{2}$-rich deep waters. This assumption contrasts with the present day situation (Louanchi et al., 1999; Takahashi et al., 2002), which may be a consequence of the modern high atmospheric $\mathrm{CO}_{2}$ concentration (ca. $380 \mathrm{ppm}$ compared to ca. $280 \mathrm{ppm}$ during the pre-industrial interglacial period), because the higher partial pressure of atmospheric $\mathrm{CO}_{2}$ may limit or even reverse the "outgassing" from the ocean. Such a shift from a $\mathrm{CO}_{2}$ source to a $\mathrm{CO}_{2}$ sink between pre-industrial time and present is documented for the Weddell Sea located in the Atlantic Sector of the Southern Ocean (Hoppema, 2004).

According to the first hypothesis, permanent surface water stratification south of the APF, possibly in response to sea-ice expansion, acted as a major contributor to the $\mathrm{CO}_{2}$ drop during the last glacial period (Francois et al., 1997; Sigman and Boyle, 2000). The stratification of the upper water column would have reduced vertical mixing and thus prevented the ventilation of $\mathrm{CO}_{2}$-rich deep water. The second hypothesis differs in that the glacial expansion of the sea-ice coverage itself causes reduced release of $\mathrm{CO}_{2}$ from the ocean to the atmosphere, possibly accompanied by seasonal deep-water stratification (Frank et al., 2000; Stephens and Keeling, 2000; Keeling and Stephens, 2001). Although these hypotheses are related, they are distinct, and both have proved problematic (e.g. Keeling and Visbeck, 2001; Sigman and Boyle, 2001).

Modelling results by Morales Maqueda and Rahmstorf (2002) and a data compilation recently published by Kohfeld et al. (2005) suggest that both mechanisms are insufficient to explain the full amount of global $\mathrm{CO}_{2}$ decrease during the last glacial period (cf. Francois et al., 1997). Nevertheless, the idea of polar stratification triggering global climate change has persisted and even expanded to a concept of bipolar oceanic stratification: this was proposed as an effective mechanism to lock up atmospheric $\mathrm{CO}_{2}$ by sequestering carbon in the deep sea and to amplify global cooling under generally cool climate conditions. Sigman et al. (2004) linked the well documented onset of stratification in the Northwest Pacific, which coincided with the late Pliocene intensification of Northern Hemisphere glaciation (Haug et al., 1999), to a synchronous onset of watercolumn stratification in the modern SIZ. Similarly, Jaccard et al. (2005a) suggested that global $\mathrm{CO}_{2}$ drawdown during cool episodes throughout the last 450 kyr originated in a simultaneous increase of ocean stratification in the Subarctic Northwest Pacific and south of the APF.

Here we show that the sedimentary records from the Atlantic and Pacific sectors of the Southern Ocean, which were used to corroborate the concept of bipolar stratification (for locations see Fig. 1), lack direct evidence for increased stratification of the water column both during the late Pliocene and late Quaternary. Rather, the drop in biological productivity recorded at these sites is likely to have resulted from an expansion of the Antarctic sea-ice coverage as previously suggested (Frank et al., 1995; Nürnberg et al., 1997; Bonn et al., 1998; Frank et al., 2000; Hillenbrand and Fütterer, 2001; Hillenbrand et al., 2002).

\section{Materials and methods}

We mainly present previously published data sets of sediment cores recovered during Ocean Drilling Program (ODP) Leg 145 (Subarctic Northwest Pacific), ODP Leg 177 (Subantarctic Southeast Atlantic), ODP Leg 178 (Pacific continental margin of the Antarctic Peninsula), ODP Leg 188 (Antarctic continental rise in the Indian sector of the Southern Ocean), and numerous expeditions with RV "Polarstern" to the Atlantic and Pacific sectors of the Southern Ocean (Fig. 1, Table 1). All analytical methods are given in the references for the data sources in Table 1. The age models used for our study are provided in the original references (Table 1) and in Appendices 1-8, Background Data Set. In the following, we highlight the new data sets generated for this study and modifications to the original data sets.

In contrast to Hillenbrand and Fütterer (2001), we used the revised composite depth scales and the revised age models for the three ODP Leg 178 sites, which were provided by Barker (2001) and Acton et al. (2002), respectively. The age models for sites 1095, 1096, and 1101 are based on magnetostratigraphy. Here, we refer the magnetostratigraphic datums to recovery-corrected composite depths (Appendices 1-3, Background Data Set; cf. Hillenbrand and Ehrmann, 2005). The palaeomagnetic-based age models at the three ODP Leg 178 sites are in general agreement with age control points provided by biostratigraphy as summarized by Iwai et al. (2002). However, because of several offsets between biostratigraphy and magnetostratigraphy discussed in Iwai et al. (2002), we also constructed age models based exclusively on biostratigraphic age control points (Appendices 4a, 5a, and 6a, Background Data Set). In some intervals at sites 1095, 1096, and 1101, the use of biostratigraphic zonal schemes for different species groups (diatoms, radiolarians, and calcareous nannofossils) resulted in an inverse stratigraphic order (Iwai et al., 2002). Therefore, we computed hypothetical (but rather unlikely) age models for each Leg 178 site, selecting those biostratigraphic datums which provide continuous 


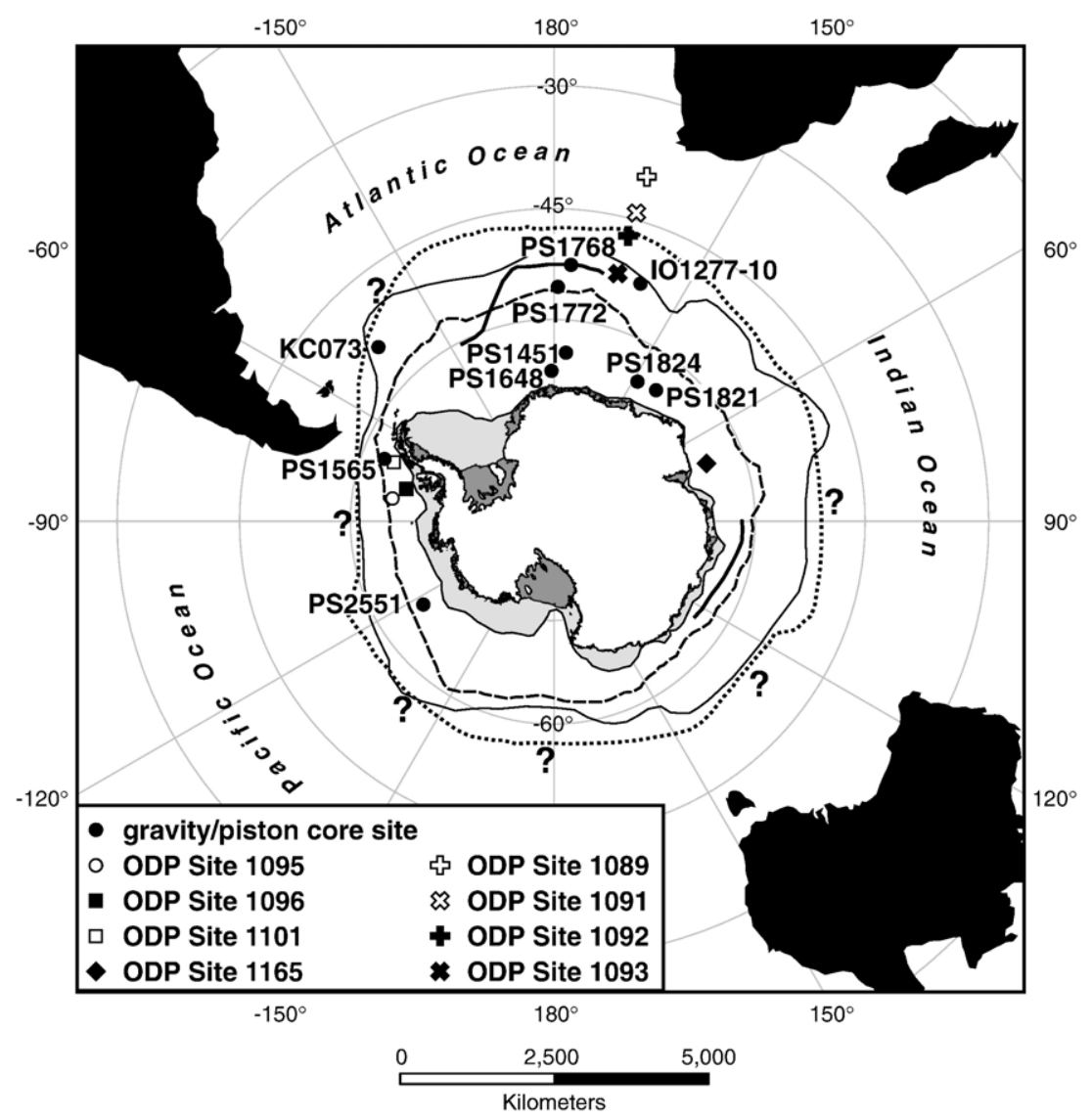

Fig. 1. Map of the Southern Ocean showing the locations of Ocean Drilling Program (ODP) drill cores and shorter sediment cores mentioned in this study. Also shown are ice shelves (dark-grey shaded), the present Antarctic Polar Front (APF, after Belkin and Gordon, 1996; thin line), the modern summer sea-ice coverage (light-grey shaded), and the sea-ice edges for modern winter (dashed line), LGM summer (bold line) and LGM winter (dotted line) according to Gersonde et al. (2005). The area between the modern summer and winter sea-ice edges delineates the present seasonal ice zone (SIZ) and the area between the modern winter sea-ice edge and the APF delineates the modern permanent open-ocean zone (POOZ). The area between the LGM summer and the LGM winter sea-ice edges corresponds to the glacial SIZ.

age progression with depth (Appendices 4a, 5a, and 6a, Background Data Set). The age models for the RV "Polarstern" cores PS1451 and PS1824 are based on radiolarian- and diatom-stratigraphy (PS1824) and combined magneto-biostratigraphy (PS1451) (Appendices 7 and 8, Background Data Set). Two hiatus spanning the time intervals from ca. 0.8 to $2.33 \mathrm{Ma}$ and ca. 3.26 to $3.58 \mathrm{Ma}$ are reported for core PS1451.

Accumulation rates of opal $\left(\mathrm{MAR}_{\mathrm{Opal}}\right)$ were calculated by multiplying the biogenic opal content with the linear sedimentation rate (LSR) and the dry-bulk density (DBD). The opal contents and the DBD at sites 1095, 1096 and 1101 were analyzed on different sets of samples (Barker et al., 1999; Hillenbrand and Fütterer, 2001). However, the downcore variability of the DBD values at the three sites is relatively small (Volpi et al., 2001). Therefore, we multiplied the opal content of a sample with the average DBD of the 10-metre long core that this sample was taken from, as well as with the corresponding LSR (instead of splicing the data sets for biogenic opal and DBD by resampling and multiplying them with the LSR, cf. Hillenbrand and Fütterer, 2001). The average DBD for each 10-metre long core was calculated by taking the arithmetic mean of all DBD values measured on that core (generally three, Barker et al., 1999). On some cores, however, no DBD was analyzed (Barker et al., 1999). In order to obtain a DBD value for such a core, we used the average of the two DBD values just calculated for the 10-metre long cores lying directly above and below it. Alternatively, the average DBD for an overlapping core drilled in another hole at the same site was used. We also calculated $\mathrm{MAR}_{\mathrm{Opal}}$ at the Leg 178 sites using the biostratigraphic-based age models (Appendices $4 \mathrm{~b}$, $5 \mathrm{~b}$, and $6 \mathrm{~b}$, Background Data Set).

In our study, we use contents of opal and biogenic barium $\left(\mathrm{Ba}_{\mathrm{bio}}\right)$ and $\mathrm{MAR}_{\mathrm{Opal}}$ for a semi-quantitative 
Table 1

Location, water depth, data sets and data sources for the cores used in this study

\begin{tabular}{|c|c|c|c|c|c|}
\hline Site & Latitude & Longitude & Water depth $(\mathrm{m})$ & Data sets & Data sources \\
\hline ODP882 & $50^{\circ} 21.8^{\prime} \mathrm{N}$ & $167^{\circ} 36.0^{\prime} \mathrm{E}$ & 3255 & $\begin{array}{l}\text { Opal, MAR } \text { Opal } \\
\delta^{15} \mathrm{~N}\end{array}$ & $\begin{array}{l}\text { Haug, 1996; } \\
\text { Sigman et al., } 2004\end{array}$ \\
\hline ODP1089 & $40^{\circ} 56.2^{\prime} \mathrm{S}$ & $09^{\circ} 53.6^{\prime} \mathrm{E}$ & 4620 & MAR $_{\text {Opal }}$ & Cortese et al., 2004 \\
\hline ODP1091 & $47^{\circ} 05.7^{\prime} \mathrm{S}$ & $05^{\circ} 55.2^{\prime} \mathrm{E}$ & 4366 & $\mathrm{MAR}_{\text {Opal }}$ & Cortese et al., 2004 \\
\hline ODP1092 & $46^{\circ} 24.7^{\prime} \mathrm{S}$ & $07^{\circ} 04.8^{\prime} \mathrm{E}$ & 1974 & $\mathrm{MAR}_{\text {Opal }}$ & Cortese et al., 2004 \\
\hline ODP1093 & $49^{\circ} 58.6 ’ \mathrm{~S}$ & $05^{\circ} 51.9^{\prime} \mathrm{E}$ & 3624 & $\mathrm{MAR}_{\text {Opal }}$ & Cortese et al., 2004 \\
\hline ODP1095 & $66^{\circ} 59.1 ’ \mathrm{~S}$ & $78^{\circ} 29.3^{\prime} \mathrm{W}$ & 3853 & Opal, MAR & $\begin{array}{l}\text { Hillenbrand and Fütterer, 2001; } \\
\text { Hillenbrand and Ehrmann, 2005 }\end{array}$ \\
\hline ODP1096 & $67^{\circ} 34.0 ’ \mathrm{~S}$ & $76^{\circ} 57.8^{\prime} \mathrm{W}$ & 3164 & Opal, MAR Opal & $\begin{array}{l}\text { Hillenbrand and Fütterer, 2001; } \\
\text { Hillenbrand and Ehrmann, 2005 }\end{array}$ \\
\hline ODP1101 & $64^{\circ} 22.3^{\prime} \mathrm{S}$ & $70^{\circ} 15.7^{\prime} \mathrm{W}$ & 3291 & Opal, MAR Opal & $\begin{array}{l}\text { Hillenbrand and Fütterer, 2001; } \\
\text { Hillenbrand and Ehrmann, 2005 }\end{array}$ \\
\hline ODP1165 & $64^{\circ} 22.8^{\prime} \mathrm{S}$ & $67^{\circ} 13.1^{\prime} \mathrm{E}$ & 3537 & Silicoflagellates; sea-ice diatoms & $\begin{array}{l}\text { Whitehead and Bohaty, 2003; } \\
\text { Whitehead et al., } 2005\end{array}$ \\
\hline PS1451 & $64^{\circ} 33.5 ’ S$ & $05^{\circ} 26.8^{\prime} \mathrm{E}$ & 3596 & Opal & Hillenbrand and Ehrmann, 2005 \\
\hline PS1565 & $63^{\circ} 54.5^{\prime} \mathrm{S}$ & $69^{\circ} 30.5^{\prime} \mathrm{W}$ & 3427 & $\mathrm{Ba}_{\text {bio }}$ & Hillenbrand and Fütterer, 2001 \\
\hline PS1648 & $69^{\circ} 44.0^{\prime} \mathrm{S}$ & $06^{\circ} 31.0^{\prime} \mathrm{E}$ & 2529 & $\mathrm{Ba}_{\text {bio }}$ & Bonn et al., 1998 \\
\hline PS1768 & $52^{\circ} 35.6 ’ \mathrm{~S}$ & $04^{\circ} 28.5^{\prime} \mathrm{E}$ & 3270 & $\mathrm{Ba}_{\text {bio }}$; sea-ice diatoms & $\begin{array}{l}\text { Nürnberg et al., 1997; } \\
\text { Gersonde and Zielinski, } 2000\end{array}$ \\
\hline PS1772 & $55^{\circ} 27.5^{\prime} \mathrm{S}$ & $01^{\circ} 09.8^{\prime} \mathrm{E}$ & 4135 & $\mathrm{Ba}_{\text {bio }}$; sea-ice diatoms & $\begin{array}{l}\text { Nürnberg et al., 1997; } \\
\text { Gersonde and Zielinski, } 2000\end{array}$ \\
\hline PS1821 & $67^{\circ} 03.1^{\prime} \mathrm{S}$ & $37^{\circ} 28.1^{\prime} \mathrm{E}$ & 4027 & $\mathrm{Ba}_{\text {bio }}$ & Bonn et al., 1998 \\
\hline PS1824 & $65^{\circ} 55.6 ’ \mathrm{~S}$ & $30^{\circ} 38.5^{\prime} \mathrm{E}$ & 4483 & Opal & Hillenbrand and Ehrmann, 2005 \\
\hline PS2551 & $69^{\circ} 48.9^{\prime} \mathrm{S}$ & $117^{\circ} 01.5^{\prime} \mathrm{W}$ & 3278 & $\mathrm{Ba}_{\text {bio }}$ & Hillenbrand et al., 2002 \\
\hline
\end{tabular}

characterization of changes in biological productivity. We consider that accumulation rates in the Southern Ocean can be crucially influenced by syndepositional lateral sediment redistribution (winnowing and focussing) leading to misinterpretations of absolute sedimentary fluxes (e.g. Frank et al., 1996; Pondaven et al., 2000; Francois et al., 2004; Geibert et al., 2005). As these authors point out, normalization to ${ }^{230} \mathrm{Th}$ is the most appropriate tool for correcting accumulation rates to vertical rain rates, but such a correction is only possible for sediments younger than $300 \mathrm{ka}$ (e.g. Francois et al., 2004). In our paper, we present $\mathrm{MAR}_{\text {Opal }}$ values on time scales back to $9.5 \mathrm{Ma}$, and therefore a ${ }^{230} \mathrm{Th}$ normalization for lateral sediment redistribution was impossible. Because $\mathrm{MAR}_{\text {Opal }}$ can be biased by better opal test preservation as a consequence of higher burial rates, which may be significantly controlled by sediment focussing (e.g. Frank et al., 2000), we also present contents of biogenic opal as they may represent a more reliable proxy for productivity (e.g. Hillenbrand and Fütterer, 2001). In Fig. 5, we present downcore variations of biogenic barium $\left(\mathrm{Ba}_{\text {bio }}\right)$ for describing temporal productivity changes in the Atlantic and Pacific sectors of the Southern Ocean at sites located in the SIZ during the last glacial period (cf. Fig. 1). However, we point out that ${ }^{230} \mathrm{Th}$-normalized vertical $\mathrm{Ba}_{\text {bio }}$ rain rates published for sediment cores recovered from these areas corroborate our interpretation of the temporal variations of the $\mathrm{Ba}_{\text {bio }}$ content (e.g. Frank et al., 1995; Nürnberg et al., 1997; Ceccaroni et al., 1998; Frank et al., 2000; Chase et al., 2003).

All opal and biogenic barium data presented in our study are available from the PANGAEA data bank of the Alfred Wegener Institute for Polar and Marine Research, Bremerhaven, Germany (http://www.pangaea.de/home/ chillenbrand).

\section{Results and discussion}

\subsection{The late Pliocene cooling step}

At ODP Leg 145 Site 882 in the Subarctic Northwest Pacific a major change in sedimentation, which is marked by a drop of the biogenic opal content and opal accumulation rate (MAR Opal $_{1}$ Fig. 2) and by the onset of the deposition of ice-rafted debris, occurred at $2.73 \mathrm{Ma}$ (e.g. Haug, 1996; Maslin et al., 1996). This change has been linked to the onset of permanent water-column stratification in response to the development of a steep vertical gradient in salinity (i.e. a halocline), which was inferred from various proxies for plankton productivity and nutrient utilization in the surface waters, for example, an increase of nitrogen-isotope $\left(\delta^{15} \mathrm{~N}\right)$ ratios (Haug et al., 1999, 2005; Swann et al., 2006). A late Pliocene increase 


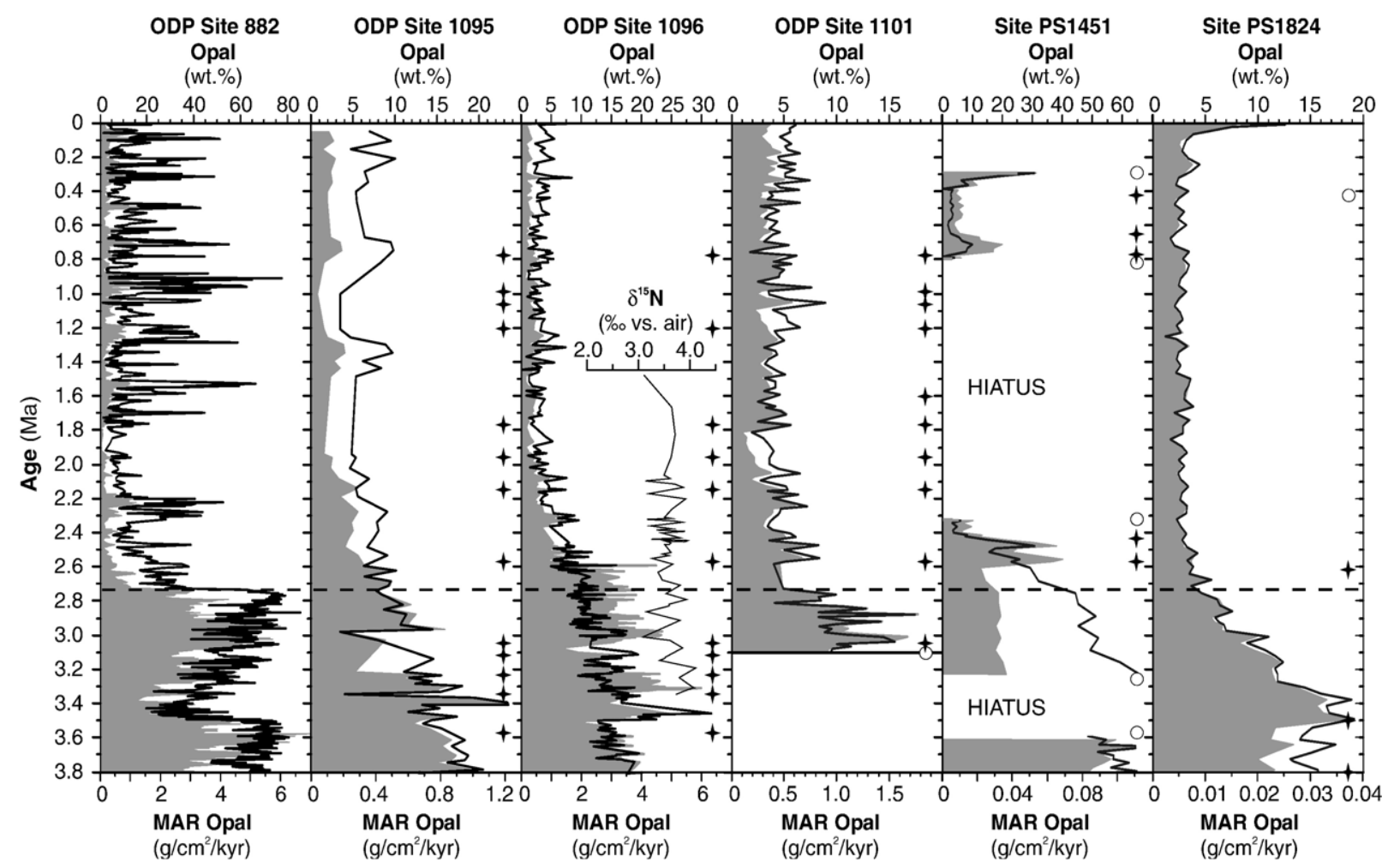

Fig. 2. Contents of biogenic opal (black lines) and mass-accumulation rates of biogenic opal (MAR Opal $_{\text {; }}$ grey-shaded areas) at ODP Leg 145 Site 882 in the NW Pacific (Haug, 1996) and ODP Leg 178 drill sites and RV "Polarstern" gravity core sites in the Southern Ocean (Hillenbrand and Ehrmann, 2005 ) during the last 3.8 Myr. Note different scaling for opal contents and MAR $\mathrm{Mpal}_{1} \delta^{15} \mathrm{~N}$ ratios for Site 1096 (Sigman et al., 2004) are also shown. Age-depth tie points for the Southern Ocean cores are based on magneto- or biostratigraphy and depicted by black stars. Older age-depth tie points are available for cores 1095, 1096, PS1451 and PS1824 (Appendices 1-5, Background Data Set). Open circles mark both interpolated and extrapolated ages. The horizontal dashed line marks the onset of large scale Northern Hemisphere glaciation at 2.73 Ma.

of stratification in the Southern Ocean was proposed on the basis of a prominent MAR $_{\text {Opal }}$ decline observed at ODP Leg 178 Site 1096, which was drilled on the Pacific continental margin of the Antarctic Peninsula (Fig. 2; Sigman et al., 2004). However, $\delta^{15} \mathrm{~N}$ ratios at Site 1096, which were used as a proxy for nutrient utilization in the surface waters and thus for possible stratification (Sigman et al., 2004), remain largely unchanged throughout the upper Pliocene and lowermost Quaternary sequence (Fig. 2 ), and therefore do not suggest an onset of stratification.

A comparison between Site 1096 and other sedimentary records from the modern SIZ (core locations given in Fig. 1 and Table 1) suggests a time transgressive decline of MAR ${ }_{\text {Opal }}$ during the late Pliocene (Fig. 2). The timescale at ODP Site 882 is based on magnetostratigraphy and an astronomically-calibrated age model between the palaeomagnetic age control points, which was established by fine-tuning of density oscillations in the orbital precession band to the summer insolation at $65^{\circ} \mathrm{N}$ (Haug, 1996). In contrast, the age models for the Southern Ocean records are exclusively based on magnetostratigraphy or combined magneto-biostratigraphy, which give only low temporal resolution and exhibit major changes in sedimentation rate at age-depth tie points (Appendices 1-3, Background Data Set). For example, at Site 1096 $\mathrm{MAR}_{\mathrm{Opal}}$ drops at $2.58 \mathrm{Ma}$ mainly as a consequence of the major decrease of sedimentation rate at the Matuyama/ Gauss chron boundary, which was used as an age-depth tie point in the age model (Appendix 2, Background Data Set; Acton et al., 2002). In contrast, the opal contents decrease more gently from $3.04 \mathrm{Ma}$ (representing the next older age control point) to $2.58 \mathrm{Ma}$. At Site 1101 , which is located relatively close to Site 1096 , both $\mathrm{MAR}_{\mathrm{Opal}}$ and opal content drop a little earlier around 2.7 Ma (Fig. 2). However, because of the relatively low resolution of the age model, MAR $_{\text {Opal }}$ decrease at Site 1101 can only be constrained to some time between 3.04 and $2.58 \mathrm{Ma}$. Furthermore, considering the general $\mathrm{MAR}_{\mathrm{Opal}}$ decrease at Site 1095 throughout the last 9.5 Myr (Fig. 3), the late Pliocene MAR $_{\text {Opal }}$ drop at Site 1096 may be interpreted as the last step of a late Neogene long-term decline of $\mathrm{MAR}_{\text {Opal }}$ on the Pacific margin of the Antarctic 


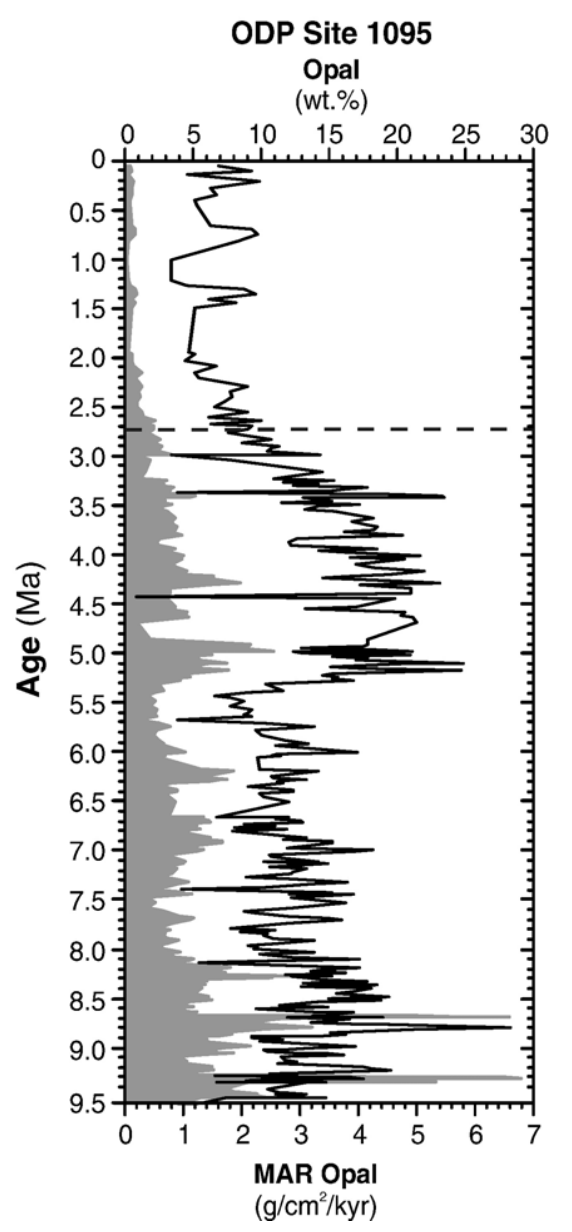

Fig. 3. Contents of biogenic opal (black line) and mass-accumulation rates of biogenic opal $\left(\mathrm{MAR}_{\mathrm{Opal}}\right.$; grey-shaded area) at ODP Leg 178 Site 1095 during the last $9.5 \mathrm{Myr}$. The horizontal dashed line marks the onset of large scale Northern Hemisphere glaciation at 2.73 Ma.

Peninsula. We point out that at the Leg 178 sites also hypothetical MAR $_{\text {Opal }}$ values, which were calculated on the basis of alternative age models using only biostratigraphic datums, fail to give any evidence for a synchronous $\mathrm{MAR}_{\mathrm{Opal}}$ drop at $2.73 \mathrm{Ma}$ (Appendices $4 \mathrm{~b}, 5 \mathrm{~b}$, and 6b, Background Data Set).

Opal accumulation rates, however, can be biased by better opal preservation as a consequence of higher burial rates, and biogenic opal content may represent a more reliable proxy (e.g. Hillenbrand and Fütterer, 2001). The late Pliocene decrease of opal content in the modern SIZ of the Atlantic and Pacific sectors spans the time interval from ca. 3.3 Ma to 2.3 Ma (Fig. 2; Hillenbrand and Ehrmann, 2005). Thus, the opal content in these sedimentary records does not exhibit such a sharp drop as that reported by Maslin et al. (1996) for the Subarctic North Pacific (Fig. 2). The late Pliocene decrease of opal deposition in the SIZ was originally interpreted as reflective a decrease in diatom productivity due to an increase of sea-ice coverage (Abelmann et al., 1990; Hillenbrand and Fütterer, 2001; Hillenbrand and Ehrmann, 2005). Remarkably, micropalaeontological data from ODP Leg 188 Site 1165 in the Indian Sector of the Southern Ocean indicate that during the early and middle Pliocene surface water temperatures south of the APF were, episodically, up to ca. $5^{\circ} \mathrm{C}$ higher than today (Whitehead and Bohaty, 2003), and sea-ice coverage was significantly reduced between ca. $5 \mathrm{Ma}$ and $2.3 \mathrm{Ma}$ (Whitehead et al., 2005) (Fig. 4). These findings suggest that the late Pliocene decrease of biosiliceous export productivity south of the APF resulted from pronounced sea-ice expansion associated with prominent Southern Ocean cooling.

Sigman et al. (2004) argued that the late Pliocene MAR $_{\text {Opal }}$ decline at Site 1096 is unlikely to reflect a decrease in opal export production, because that would have caused an extreme enrichment of dissolved silicate in surface waters after 2.7 Ma. However, this is exactly what is suggested by sedimentary records from ODP Leg 177 sites located in the present POOZ and north of the modern APF, as they exhibit increased opal deposition after ca. 2.5 Ma, indicating a northward shift of the dissolved silica pool and the associated opal depocentre within the Southern Ocean (Fig. 4; Cortese et al., 2004). Thus, the late Pliocene decrease of biological production in the SIZ is more likely to originate from a general expansion of the annual sea-ice coverage in response to global cooling. Whether this sea-ice expansion did cause the development of a strongly stratified upper ocean layer during the summer months (cf. Stephens and Keeling, 2000) remains hypothetical.

\subsection{Biological productivity south of the Antarctic Polar Front during late Quaternary glacial periods}

Jaccard et al. (2005a) interpreted increased glacial stratification in the Subarctic Northwest Pacific and the modern SIZ and POOZ of the Southern Ocean during the last $450 \mathrm{kyr}$ from minima in $\mathrm{Ba}_{\text {bio }}$ content observed at Site 882 and in sediment cores recovered from the Atlantic and Pacific sectors of the Southern Ocean (Fig. 5). These $\mathrm{Ba}_{\text {bio }}$ minima have been interpreted as reflecting minima in export production (e.g. Nürnberg et al., 1997; Bonn et al., 1998; Hillenbrand and Fütterer, 2001; Hillenbrand et al., 2002). With the exception of site PS1772, which is located south of the present maximum winter sea-ice boundary, and site PS1768, the core sites presented by Jaccard et al. (2005a) from the Atlantic and Pacific sectors of the Southern Ocean are located within the modern SIZ (Fig. 1), where the average sea-ice season lasts for five to eight months per 


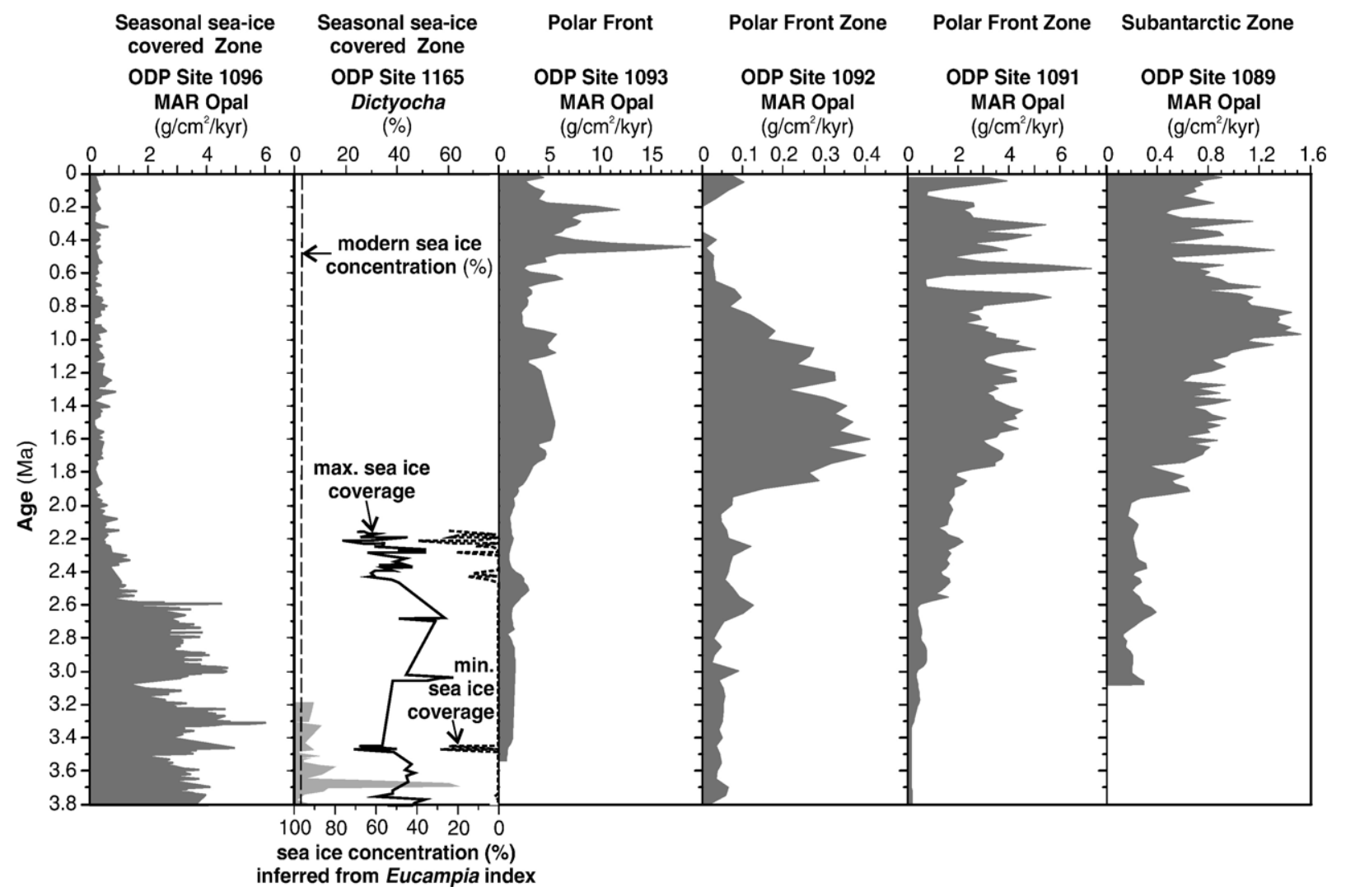

Fig. 4. Mass-accumulation rates of biogenic opal (MAR Opal; grey-shaded area) at ODP Leg 178 Site 1096 and at ODP Leg 177 sites 1089,1091 , 1092, and 1093 (Cortese et al., 2004) during the last 3.8 Myr. Abundances of the silicoflagellate genus Dictyocha (grey-shaded area; Whitehead and Bohaty, 2003) and sea-ice concentration (black line: maximum sea-ice coverage, dotted line: minimum sea-ice coverage, vertical dashed line: presentday sea-ice concentration; Whitehead et al., 2005) at ODP Leg 188 Site 1165 during the Pliocene are also shown. Dictyocha is common in modern, relatively warm subantarctic surface waters (Whitehead and Bohaty, 2003). The sea-ice concentration was reconstructed from the proportion of the diatom species Eucampia antarctica with intercalary valves (Eucampia index; Whitehead et al., 2005).

year (Bonn et al., 1998; Hillenbrand and Fütterer, 2001; Hillenbrand et al., 2002). Accordingly, air-sea exchange of $\mathrm{CO}_{2}$ is reduced during these periods of time. The winter sea-ice coverage in the SIZ results in a strong stratification of the upper water column during the summer months, when a suspended layer of sub-zero (lower than $0{ }^{\circ} \mathrm{C}$ ) "winter water" causes a strong thermocline, which generates a strong pycnocline substantially reducing vertical mixing and thus upwelling of $\mathrm{CO}_{2}$-rich deep water (e.g. Honjo, 2004). Consequently, any glacial shut-down of the $\mathrm{CO}_{2}$ exchange between ocean and atmosphere in the region corresponding to the modern SIZ cannot have influenced the global $\mathrm{CO}_{2}$ budget noticeably, as even under modern conditions $\mathrm{CO}_{2}$ outgassing in this area is heavily impaired by either the presence of sea ice or by a strongly stratified water column. Similarly to the late Pliocene decline in biogenic opal deposition, the reduction of biological productivity in the SIZ during late Quaternary glacial periods is more likely to have originated from a prolonged seasonal (or even permanent) sea-ice coverage as previously suggested (Nürnberg et al., 1997; Bonn et al., 1998; Hillenbrand and Fütterer, 2001; Hillenbrand et al., 2002; cf. Gersonde et al., 2005).

Accumulation rates of $\mathrm{Ba}_{\text {bio }}$ and biogenic opal in the Atlantic and Pacific sectors of the Southern Ocean, even when corrected for winnowing and focussing, indicate that during the last glacial period export production was at its minimum not only in the modern SIZ (Frank et al., 1995; Ceccaroni et al., 1998), but also in the presently sea-ice free POOZ (Nürnberg et al., 1997; Frank et al., 2000; Chase et al., 2003). For example, at site PS1772, which is located at the boundary between the present SIZ and POOZ (Nürnberg et al., 1997; Gersonde and Zielinski, 2000), and site PS1768 in the modern POOZ, the abundance of sea-ice adapted diatom species in sediments from the last glacial period gives clear evidence that this area was heavily affected by sea-ice coverage, i.e. both sites were located in the SIZ during 

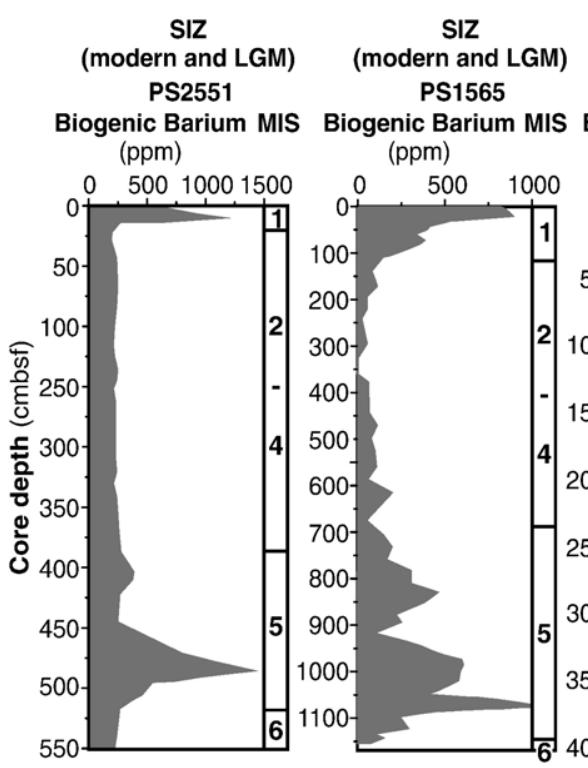
(ppm)

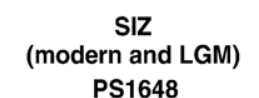

PS1648

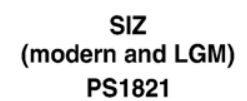

PS1821

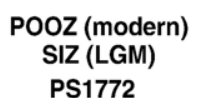

(ppm) (ppm)

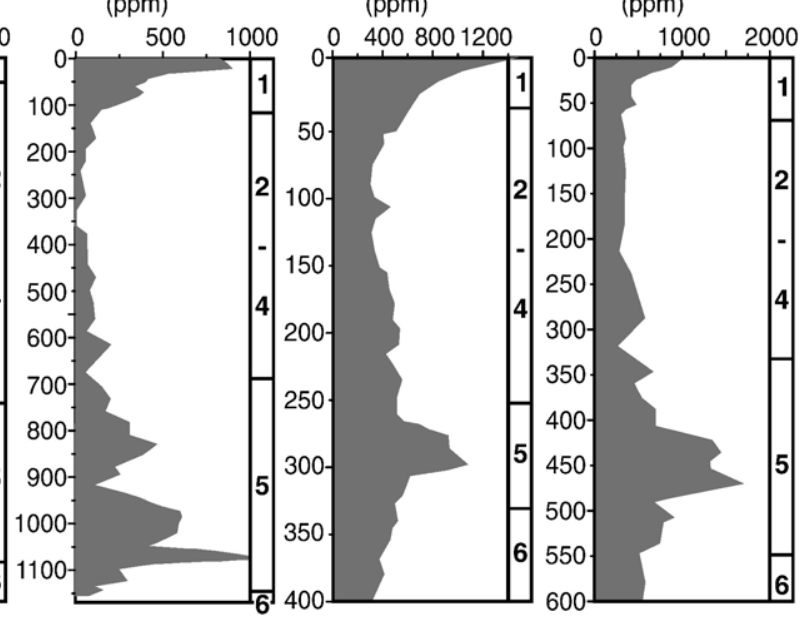

\section{POOZ (modern) SIZ (LGM)}

PS1768

nic Barium MIS

(ppm)

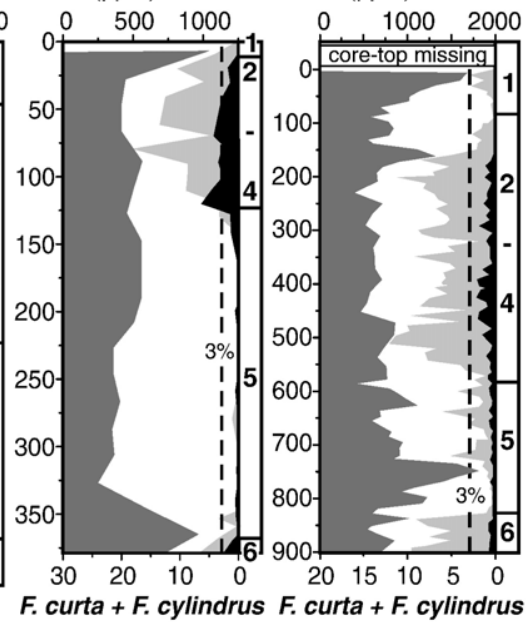

(\%)

F. obliquecostata

(\%)

(\%)

F. obliquecostata

(\%)

Fig. 5. Contents of biogenic barium ( $\mathrm{Ba}_{\text {bio }}$, grey-shaded area) at core sites PS2551 (Hillenbrand et al., 2002), PS1565 (Hillenbrand and Fütterer, 2001), PS1648 and PS1821 (Bonn et al., 1998) in the present seasonal sea-ice zone (SIZ) and at sites PS1772 and PS1768 in the modern permanent open-ocean zone (POOZ) (Nürnberg et al., 1997). For sites PS1772 and PS1768 relative concentrations of the sea-ice indicator diatoms Fragilariopsis cylindrus and Fragilariopsis curta (light-grey shaded area) and of the deep-temperature adapted diatom Fragilariopsis obliquecostata (black area) are also shown. Vertical dashed line marks a threshold abundance of $3 \%$ indicating seasonal winter sea-ice coverage (F. cylindrus plus $F$. curta) and summer sea-ice coverage (F. obliquecostata), respectively (diatom data taken from Gersonde and Zielinski, 2000), documenting that sites PS1772 and PS1768 were located in the SIZ during the last glacial period (cf. Fig. 1). MIS: Marine Isotope Stage.

the last glacial period (Figs. 1 and 5; Gersonde and Zielinski, 2000; Gersonde et al., 2003, 2005). Therefore, the observed glacial decline in biological productivity in the area corresponding to the modern POOZ, e.g. at site PS1768, which was used by Jaccard et al. (2005a) to support the idea of glacial-age increased stratification, was probably caused by an expansion of the winter seaice cover (Nürnberg et al., 1997).

In a recent publication, Abelmann et al. (2006) challenged the view that in the glacial SIZ of the Atlantic Sector of the Southern Ocean, particularly at site PS1768, biological productivity was generally lower than today. Throughout the last glacial period the authors observed an increased vertical rain rate of resting spores of the diatom genus Chaetoceros, which is abundant in surface sediments underlying modern high production areas of the Southern Ocean, and tests of the deep-living and high carbon export indicating radiolarian species Cycladophora davisiana. Abelmann et al. (2006) inferred that those areas in the modern POOZ, which were located in the SIZ during the last glacial period, were highly productive due to extensive Chaetoceros blooms during the sea-ice free summer months and characterized by high carbon, but low opal export. They attributed the decoupling of opal and carbon export to the quick recycling of the weakly silicified Chaetoceros diatom tests in the shallow waters, so that only the resting spores, which are resistant to opal dissolution, were buried in the sediments. At site PS1768, this scenario can explain the negative correlation of Chaetoceros and $C$. davisiana rain rates with opal rain rates, which may mainly depend on the production and export of heavily silicified tests of the open-ocean, low productivity indicating diatom species Fragilariopsis kerguelensis (Abelmann et al., 2006). Furthermore, the hypothesis of higher biological productivity at site PS1768 during the last glacial period does not necessarily contradict the lower $\mathrm{Ba}_{\text {bio }}$ contents (Fig. 5) and lower $\mathrm{Ba}_{\text {bio }}$ rain rates recorded during that period of time (Nürnberg et al., 1997). The sediments deposited during the last glacial maximum (LGM) at site PS1768 exhibit significant concentrations of authigenic uranium pointing to suboxic or even reducing conditions and thus possible remobilisation of barium (Frank et al., 2000; Abelmann et al., 2006). Therefore, the $\mathrm{Ba}_{\text {bio }}$ record at site PS1768 bears an element of uncertainty in terms of interpreting it as an unequivocal proxy for export production. 
We consider that the scenario suggested by Abelmann et al. (2006) might mainly have affected that area of the modern POOZ, which became the SIZ during the last glacial period. However, there are three findings which may require a refinement of their hypothesis. Firstly, similar to site PS1768 the glacial rain rates and contents of $\mathrm{Ba}_{\text {bio }}$ were low at site PS1772 (Fig. 5; Nürnberg et al., 1997). Because the corresponding sediments contain only negligible concentrations of authigenic uranium (Frank et al., 2000), the $\mathrm{Ba}_{\text {bio }}$ proxy at site PS1772, which indicates lower glacial productivity, is assumed to be reliable.

Secondly, the conclusion of Abelmann et al. (2006) that elsewhere in the glacial SIZ of the South Atlantic the abundance of Chaetoceros spores was significantly enhanced in respect to the Holocene contradicts findings of Allen et al. (2005). These authors showed for core site $\mathrm{KC} 073$ in the southwest Atlantic, which is located in the modern POOZ, but was located in the SIZ during the last glacial period (Fig. 1), that the abundance of Chaetoceros spores before $19.5 \mathrm{ka}$ was much lower than during the subsequent deglaciation period and the Holocene. It's noteworthy that Allen et al. (2005) observed the highest abundances of Chaetoceros spores during the deglaciation between $17 \mathrm{ka}$ and $13 \mathrm{ka}$ coinciding with highest abundances and vertical rain rates of Chaetoceros spores reported for site PS1768 (Abelmann et al., 2006). Nevertheless, the concentration of Chaetoceros spores at site $\mathrm{KC} 073$ remained relatively high until at least $2.5 \mathrm{ka}$ (Allen et al., 2005), while Abelmann et al. (2006) observed a sharp drop down to negligible abundances at $13 \mathrm{ka}$. We consider that Allen et al. (2005) did not calculate vertical rain rates of Chaetoceros spores. However, they found evidence for winnowing of sediments deposited between ca. $7 \mathrm{ka}$ and $1.5 \mathrm{ka}$. Thus, the rain rates of Chaetoceros spores at site $\mathrm{KC} 073$ were probably higher during the Holocene than during the last glacial period. Another discrepancy between sites PS1768 and KC073 is that contents and rain rates of Chaetoceros spores and $C$. davisiana specimens are positively correlated at site PS1768 (Abelmann et al., 2006), whereas at site $\mathrm{KC} 073$ the abundance of $C$. davisiana decreased from ca. $22 \mathrm{ka}$ to $15.5 \mathrm{ka}$ and the abundance of Chaetoceros spores increased from ca. $20 \mathrm{ka}$ to $16 \mathrm{ka}$ (Allen et al., 2005).

Finally, extensive blooms of Chaetoceros diatoms in the glacial SIZ are supposed to have coincided with increased production of the haptophyte flagellate Phaeocystis (Abelmann et al., 2006). Because Phaeocystis is a main producer of dimethylsulphide (DMS) atmospheric concentrations of DMS should have increased during the last glacial period. However, recently published analyses on the EPICA Dome C ice core do not show a glacial increase of DMS flux on the Antarctic continent suggesting that the DMS production south of the APF remained fairly constant during the last glacial period (Wolff et al., 2006).

\subsection{Clues for stratification in the Southern Ocean during the last glacial period}

With the emergence of the hypothesis that intense polar stratification may have acted as an effective mechanism for shutting down $\mathrm{CO}_{2}$ outgassing in the glacial Southern Ocean (Elderfield and Rickaby, 2000; Sigman and Boyle, 2000; Stephens and Keeling, 2000), watercolumn stratification during the summer months was taken into account as a possible consequence of the expansion of seasonal sea-ice coverage (Frank et al., 2000; Gersonde et al., 2003; Schneider-Mor et al., 2005). Most workers compared proxies for palaeoproductivity $\left(\delta^{13} \mathrm{C}\right.$ ratios in diatomaceous organic matter, $\mathrm{MAR}_{\mathrm{Opal}}$, $\left.\mathrm{Ba}_{\mathrm{bio}}\right)$ with proxies for nutrient utilization $\left(\delta^{15} \mathrm{~N}\right.$ ratios in organic matter, $\delta^{30} \mathrm{Si}$ ratios in diatom valves) and inferred oceanic stratification for times with low productivity and increased nutrient utilization (e.g. Francois et al., 1997; Crosta and Shemesh, 2002; Robinson et al., 2005). Additionally, Francois et al. (1997) and Frank et al. (2000) measured authigenic uranium and observed a maximum in authigenic uranium content within sediments deposited during the LGM at site PS1768. The authors interpreted the authigenic uranium peak to indicate a decrease in bottom water oxygen concentration and concluded that during the LGM the water column south of the APF must have been less ventilated by increased stratification. Alternatively, the reduced ventilation of the water column may have originated from increased sea-ice coverage (cf. Stephens and Keeling, 2000).

The major argument for enhanced stratification in the present POOZ, including areas in the glacial SIZ, is based on higher $\delta^{15} \mathrm{~N}$ ratios in bulk samples from glacial-age sediments in the Indian and the Atlantic sectors of the Southern Ocean, which were interpreted to indicate higher nutrient utilization in the surface waters (Francois et al., 1997). More recent studies revealed that in deep, open ocean depositional settings like the Southern Ocean, microbial diagenetic alteration may have increased the initial $\delta^{15} \mathrm{~N}$ ratio of the sedimentary organic matter (Lourey et al., 2003; Robinson et al., 2005). Elaborate $\delta^{15} \mathrm{~N}$ analyses carried out exclusively on diatom-bound organic matter confirmed a glacial increase of $\delta^{15} \mathrm{~N}$ ratios in the modern POOZ of both oceanic regions (Sigman et al., 1999; Crosta and Shemesh, 2002; Schneider-Mor et al., 2005). South of the APF, however, 
other proxies for nutrient concentration and nutrient utilization in the surface waters, such as $\mathrm{Cd} / \mathrm{Ca}$ ratios in planktonic foraminifera tests and $\delta^{30} \mathrm{Si}$ ratios in diatom valves, suggest a decrease of nutrient utilization during the LGM (Kohfeld et al., 2005).

Applying a different method of $\delta^{15} \mathrm{~N}$ measurement on diatom-bound organic matter, Robinson et al. (2004) corroborated higher glacial $\delta^{15} \mathrm{~N}$ ratios in the POOZ of the Indian Sector of the Southern Ocean. These authors also investigated core IO1277-10 from the modern POOZ in the Atlantic Sector (Fig. 1), which was located in the glacial SIZ and had been previously studied for $\delta^{15} \mathrm{~N}$ ratios by Crosta and Shemesh (2002). In contrast to the latter authors, however, the results of Robinson et al. (2004) did not confirm an increase of $\delta^{15} \mathrm{~N}$ ratios in the glacial SIZ of the Atlantic Sector. Thus, the application of different analytical techniques for $\delta^{15} \mathrm{~N}$ measurements may provide different results. Also taking into account the discrepancies between results of $\delta^{15} \mathrm{~N}$ measurements and other proxies for nutrient utilization and concentration (Kohfeld et al., 2005), $\delta^{15} \mathrm{~N}$ ratios seem not to provide unequivocal evidence for stratification. This conclusion is supported by recent seasonal studies on surface water and sediment trap samples from the Southern Ocean, indicating that an increase in $\delta^{15} \mathrm{~N}$ may originate in higher export of ${ }^{15} \mathrm{~N}$-enriched phytoplankton (Lourey et al., 2003). Because sea-ice algae may be enriched in ${ }^{15} \mathrm{~N}$, an increase of $\delta^{15} \mathrm{~N}$ in glacial-age sediments may be a consequence of a higher export of these sea-ice algae (Lourey et al., 2003), and not be related to a stratification of the upper water column. Nevertheless, in oceanic areas unaffected by sea-ice coverage even during glacial periods, e.g. north of the modern $\mathrm{APF}$, diatom-bound $\delta^{15} \mathrm{~N}$ ratios may provide useful information about changes in nutrient utilization during the late Quaternary glacial cycles (Crosta et al., 2005; Robinson et al., 2005).

\subsection{A North Atlantic cause for the Southern Ocean/ North Pacific teleconnection?}

A strong positive correlation has been described for the late Quaternary $\mathrm{Ba}_{\text {bio }}$ record at ODP Site 882 in the Northwest Pacific, the $\mathrm{Ba}_{\text {bio }}$ record at site PS1768 in the modern POOZ/glacial SIZ, and the temperature record from the Vostok ice core drilled in Antarctica (Jaccard et al., 2005a). The simultaneity and similar amplitude of the fluctuations of the three records have been interpreted that glacial-interglacial changes in Antarctic deep-water production modulated the stratification in the Subarctic Pacific, and thus the degree of biological productivity (Jaccard et al., 2005a). We already presented evidence that the glacial reduction in biological productivity at site PS1768 can be explained with a longer duration of annual sea-ice coverage, which would be consistent with lower air temperatures in the Southern Ocean and on the Antarctic continent during the last glacial period indicated by the Vostok temperature record.

We propose that the strong temporal correlation of the $\mathrm{Ba}_{\text {bio }}$ record from the Subarctic Pacific with the $\mathrm{Ba}_{\text {bio }}$ record from the modern POOZ and the Antarctic temperature record may mainly result from the technique applied for establishing a high-resolution age model for ODP Site 882. Only three biostratigraphic datums and low resolution oxygen-isotope curves measured on benthic and planktonic foraminifera were obtained from sediments younger than $450 \mathrm{ka}$ at Site 882 (Haug, 1996; Appendices 9a and 9b, Background Data Set). Because these datums were insufficient for establishing an appropriate age model, the density record at Site 882 , which inversely reflects the opal content (and thus possibly the $\mathrm{Ba}_{\text {bio }}$ content as well), was orbitally tuned, and the benthic foraminiferal $\delta^{18} \mathrm{O}$ curve was matched with the benthic oxygen-isotope stratigraphy from a neighbouring core site via the curves of magnetic susceptibility (Haug, 1996). For the last $150 \mathrm{kyr}$, the $\mathrm{Ba}_{\text {bio }}$ record for Site 882 was directly matched with the Vostok temperature record, which required time shifts (up to $5 \mathrm{kyr}$ ) of the original age control points for Site 882 (Jaccard et al., 2005b). Therefore, the apparent covariation of palaeoproductivity in the Subarctic Pacific with palaeoproductivity in the Southern Ocean and air temperatures in Antarctica on orbital time scales may simply result from the simultaneity of global climate changes at these time scales. The apparent strong temporal coupling between Site 882 and the Vostok ice core on sub-orbital time scales during the last $150 \mathrm{kyr}$ may be caused by matching the $\mathrm{Ba}_{\text {bio }}$ record at Site 882 with the Vostok temperature record.

Of course, we do not exclude the possibility that the oceanographic changes in the Subarctic Pacific during the late Quaternary coincided with oceanographic changes in the Southern Ocean and climate changes in Antarctica. However, such a linkage might be a temporal rather than a direct causal relationship. Alternatively, we suggest that variations in the global deep-water circulation may have caused the strong similarities in biological production between the Subarctic Northwest Pacific and the region south of the APF. Undoubtedly, the $\mathrm{Ba}_{\mathrm{bio}}$ record at Site 882 documents productivity changes on glacial-interglacial time scales unrelated to variations in sea-ice coverage because Site 882 was located south of the North Pacific sea-ice limit during late Quaternary glacial periods (Jaccard et al., 2005a). The pronounced maxima in $\mathrm{CaCO}_{3}$ content observed at Site 882 during peak interglacials have been 
interpreted to indicate times of higher calcite saturation state in bottom water caused by an interglacial weakening of the North Pacific halocline (Jaccard et al., 2005a). We consider that each major peak in $\mathrm{CaCO}_{3}$ content correlates with a maximum in $\mathrm{Ba}_{\text {bio }}$ content. This correlation indicates that the $\mathrm{CaCO}_{3}$ record may also carry a signal of productivity of calcareous plankton (cf. Haug, 1996). However, taking into account the lack of correspondence between $\mathrm{Ba}_{\text {bio }}$ and $\mathrm{CaCO}_{3}$ content during the late periods of Marine Isotope Stages 11 (ca. 420-360 ka), 9 (ca. 339$330 \mathrm{ka}$ ) and 7 (ca. 245-186 ka) (Jaccard et al., 2005a), a rather complex temporal relationship between various proxies for productivity at Site 882 becomes obvious as described by Haug (1996).

Nevertheless, a low resolution $\mathrm{CaCO}_{3}$ record at Site 882 showed that major $\mathrm{CaCO}_{3}$ peaks coincide with maxima in carbon-isotope ratios analyzed on benthic foraminifera at ODP Leg 108 Site 659 in the equatorial eastern Atlantic (Haug, 1996). The better carbonate preservation in the Subarctic North Pacific during interglacial periods may have resulted from an increased deep-water ventilation (Haug, 1996). During late Pliocene and Quaternary warm periods the formation of North Atlantic Deep Water (NADW), which is the main driver of global deep-water convection, was stronger (e.g. Bickert et al., 1997). Consequently, upwelling of deep water in the Northwest Pacific, at the terminus of the deep-water conveyor belt, might have intensified during interglacial times (Haug, 1996; Maslin et al., 1996), which facilitated carbonate preservation on the seafloor and promoted biological productivity in the surface waters by weakening the halocline and thus reducing stratification (Haug, 1996; Jaccard et al., 2005a). Considering that NADW probably also regulated the supply of warmth to the Southern Ocean on glacial-interglacial time scales (e.g. Imbrie et al., 1992) and thus affected seasonal sea-ice coverage as well, changes in NADW flux might explain synchronous changes south of the APF and in the Subarctic Northwest Pacific, without a need for enhanced ocean stratification in the Southern Ocean.

\section{Conclusions}

The late Pliocene decrease of biogenic silica deposition south of the modern APF occurred both diachronously and gradually between ca. 3.3 Ma and 2.3 Ma and was unrelated to the onset of water-column stratification in the Northwest Pacific at $2.73 \mathrm{Ma}$. There is evidence that the reduction of plankton productivity in the Southern Ocean resulted from an expansion of the winter seaice coverage in response to global cooling rather than from ocean stratification. Similarly, micropalaeontological investigations on diatom assemblages indicate that decreased production in the present SIZ and POOZ of the Atlantic and Pacific sectors of the Southern Ocean during late Quaternary glacial periods resulted from increased sea-ice coverage, whereas nitrogen-isotope data used as a proxy for stratification provide ambiguous results. A strong temporal coupling of proxies for productivity in the Northwest Pacific with proxies for productivity in the glacial SIZ and air temperatures in Antarctica, may actually result, at least in part, from tuning proxy data related to palaeoproductivity at Site 882 with orbital cycles, and using an Antarctic ice-core record as a reference, respectively. Moreover, the positive correlation may document almost simultaneous interhemispheric climate changes on glacial-interglacial time scales promoted by changes in global deep-water circulation rather than a causal relationship.

\section{Acknowledgements}

We thank C. Allen, A. Crame, J. Johnson, R. Larter, D. Schmidt, M. Williams and D. Vaughan for their comments on an earlier draft, and M. Frank, T. Corrège and an anonymous reviewer for their constructive suggestions.

\section{Appendix A. Supplementary data}

Supplementary data associated with this article can be found, in the online version, at doi:10.1016/j. palaeo.2006.06.001.

\section{References}

Abelmann, A., Gersonde, R., Spiess, V., 1990. Pliocene-Pleistocene paleoceanography in the Weddell Sea: siliceous microfossil evidence. In: Bleil, U., Thiede, J. (Eds.), Geological History of the Polar Oceans: Arctic versus Antarctic. NATO ASI Ser. C 308. Kluwer Academic Publishers, Dordrecht, pp. 729-759.

Abelmann, A., Gersonde, R., Cortese, G., Kuhn, G., Smetacek, V., 2006. Extensive phytoplankton blooms in the Atlantic sector of the glacial Southern Ocean. Paleoceanography 21, PA1013, doi:10.1029/ 2005PA001199.

Acton, G.D., Guyodo, Y., Brachfeld, S.A., 2002. Magnetostratigraphy of sediment drifts on the continental rise of West Antarctica (ODP Leg 178, Sites 1095, 1096, and 1101). In: Barker, P.F., Camerlenghi, A., Acton, G.D., Ramsay, A.T.S. (Eds.), Proc. ODP Sci. Results, vol. 178. Ocean Drilling Program, College Station, TX, pp. 1-61. [Online]. Available from World Wide Web:http://www-odp.tamu. edu/publications/178_SR/VOLUME/CHAPTERS/SR178_37.PDF.

Allen, C.S., Pike, J., Pudsey, C.J., Leventer, A., 2005. Submillenial variations in ocean conditions during deglaciation based on diatom assemblages from the southwest Atlantic. Paleoceanography 20, PA2012, doi:10.1029/2004PA001055. 
Barker, P.F., 2001. Data report: composite depths and spliced sections for Leg 178 Sites 1095 and 1096, Antarctic Peninsula continental rise. In: Barker, P.F., Camerlenghi, A., Acton, G.D., Ramsay, A.T.S. (Eds.), Proc. ODP Sci. Results, vol. 178. Ocean Drilling Program, College Station, TX, pp. 1-15. [Online]. Available from World Wide Web:http://www-odp.tamu.edu/publications/178_SR/ VOLUME/CHAPTERS/SR178_06.PDF.

Barker, P.F., Camerlenghi, A., Acton, G.D., et al. (Eds.), 1999. Proc. ODP Init. Reports, vol. 178. Ocean Drilling Program, College Station, TX. [Online]. Available from World Wide Web:http:// www-odp.tamu.edu/publications/178_IR/178TOC.HTM.

Belkin, I.M., Gordon, A.L., 1996. Southern Ocean fronts from the Greenwich meridian to Tasmania. J. Geophys. Res. 101 (C2), 3675-3696.

Bickert, T., Curry, W.B., Wefer, G., 1997. Late Pliocene to Holocene (2.6-0 Ma) western equatorial Atlantic deep-water circulation: inferences from benthic stable isotopes. In: Shackleton, N.J., Curry, W.B., Richter, C., Bralower, T.J. (Eds.), Proc. ODP Sci. Results, vol. 154. Ocean Drilling Program, College Station, TX, pp. 239-253.

Bonn, W.J., Gingele, F.X., Grobe, H., Mackensen, A., Fütterer, D.K., 1998. Palaeoproductivity at the Antarctic continental margin: opal and barium records for the last $400 \mathrm{ka}$. Palaeogeogr. Palaeoclimatol. Palaeoecol. 139, 195-211.

Ceccaroni, L., Frank, M., Frignani, M., Langone, L., Ravaioli, M., Mangini, A., 1998. Late Quaternary fluctuations of biogenic component fluxes on the continental slope of the Ross Sea, Antarctica. J. Mar. Syst. 17, 515-525.

Chase, Z., Anderson, R.F., Fleisher, M.Q., Kubik, P.W., 2003. Accumulation of biogenic and lithogenic material in the Pacific sector of the Southern Ocean during the past 40,000 years. DeepSea Res. II 50, 799-832.

Cortese, G., Gersonde, R., Hillenbrand, C.-D., Kuhn, G., 2004. Opal sedimentation shifts in the World Ocean over the last 15 Myr. Earth Planet. Sci. Lett. 224, 509-527.

Crosta, X., Shemesh, A., 2002. Reconciling down core anticorrelation of diatom carbon and nitrogen isotopic ratios from the Southern Ocean. Paleoceanography 17, 1010, doi:10.1029/2000PA000565.

Crosta, X., Shemesh, A., Etourneau, J., Yam, R., Billy, I., Pichon, J.J., 2005. Nutrient cycling in the Indian sector of the Southern Ocean over the last 50,000 years. Glob. Biogeochem. Cycles 19, GB3007, doi:10.1029/2004GB002344.

Elderfield, H., Rickaby, R.E.M., 2000. Oceanic Cd/P ratio and nutrient utilization in the glacial Southern Ocean. Nature 405, 305-310.

Francois, R., Altabet, M.A., Yu, E.-F., Sigman, D.M., Bacon, M.P., Frank, M., Bohrmann, G., Bareille, G., Labeyrie, L.D., 1997. Contribution of Southern Ocean surface-water stratification to low atmospheric $\mathrm{CO}_{2}$ concentrations during the last glacial period. Nature 389, 929-935.

Francois, R., Frank, M., Rutgers van der Loeff, M.M., Bacon, M.P., 2004. ${ }^{230}$ Th normalization: an essential tool for interpreting sedimentary fluxes during the late Quaternary. Paleoceaanography 19, PA1018, doi:10.1029/2003PA000939.

Frank, M., Eisenhauer, A., Bonn, W.J., Walter, P., Grobe, H., Kubik, P.W., Dittrich-Hannen, B., Mangini, A., 1995. Sediment redistribution versus paleoproductivity change: Weddell Sea margin sediment stratigraphy and biogenic particle flux of the last 25,0000 years deduced from ${ }^{230} \mathrm{Th}_{\mathrm{ex}},{ }^{10} \mathrm{Be}$ and biogenic barium profiles. Earth Planet. Sci. Lett. 136, 559-573.

Frank, M., Gersonde, R., Rutgers van der Loeff, M., Kuhn, G., Mangini, A., 1996. Late Quaternary sediment dating and quantification of lateral sediment redistribution applying ${ }^{230} \mathrm{Th}_{\mathrm{ex}}$ : a study from the eastern Atlantic sector of the Southern Ocean. Geol. Rundsch. 85, 554-566.

Frank, M., Gersonde, R., Rutgers van der Loeff, M., Bohrmann, G., Nürnberg, C.C., Kubik, P., Suter, M., Mangini, A., 2000. Similar glacial and interglacial export bioproductivity in the Atlantic sector of the Southern Ocean: multiproxy evidence and implications for glacial atmospheric $\mathrm{CO}_{2}$. Paleoceanography 15, 642-658.

Geibert, W., Rutgers van der Loeff, M.M., Usbeck, R., Gersonde, R., Kuhn, G., Seeberg-Elverfeldt, J., 2005. Quantifying the opal belt in the Atlantic and southeast Pacific sector of the Southern Ocean by means of ${ }^{230} \mathrm{Th}$ normalization. Glob. Biogeochem. Cycles 19, GB4001, doi:10.1029/2005GB002465.

Gersonde, R., Zielinski, U., 2000. The reconstruction of late Quaternary Antarctic sea-ice distribution - the use of diatoms as a proxy for seaice. Palaeogeogr. Palaeoclimatol. Palaeoecol. 162, 263-286.

Gersonde, R., Crosta, X., Abelmann, A., Armand, L., 2005. Sea-surface temperature and sea ice distribution of the Southern Ocean at the EPILOG Last Glacial Maximum - a circum-Antarctic view based on siliceous microfossil records. Quat. Sci. Rev. 24, 869-896.

Gersonde, R., Abelmann, A., Brathauer, U., Becquey, S., Bianchi, C., Cortese, G., Grobe, H., Kuhn, G., Niebler, H.-S., Segl, M., Sieger, R., Zielinski, U., Fütterer, D.K., 2003. Last glacial sea-surface temperatures and sea-ice extent in the Southern Ocean (AtlanticIndian sector) - a multiproxy approach. Paleoceanography 18 , 1061, doi:10.1029/2002PA000809.

Haug, G.H., 1996. Zur Paläo-Ozeanographie und Sedimentationsgeschichte im Nordwest-Pazifik während der letzten 6 Millionen Jahre (ODP-Site 882). PhD Thesis, Berichte des GeologischPaläontologischen Instituts der Christian-Albrechts-Universität Kiel 78, Kiel, Germany.

Haug, G.H., Sigman, D.M., Tiedemann, R., Pedersen, T.F., Sarnthein, M., 1999. Onset of permanent stratification in the subarctic Pacific Ocean. Nature 401, 779-782.

Haug, G.H., Ganopolski, A., Sigman, D.M., Rosell-Mele, A., Swann, G.E.A., Tiedemann, R., Jaccard, S.L., Bollmann, J., Maslin, M.A., Leng, M.J., Eglinton, G., 2005. North Pacific seasonality and the glaciation of North America 2.7 million years ago. Nature 433, 821-825.

Hillenbrand, C.-D., Fütterer, D.K., 2001. Neogene to Quaternary deposition of opal on the continental rise west of the Antarctic Peninsula, ODP Leg 178, Sites 1095, 1096, and 1101. In: Barker, P.F., Camerlenghi, A., Acton, G.D., Ramsay, A.T.S. (Eds.), Proc. ODP Sci. Results, vol. 178. Ocean Drilling Program, College Station, TX, pp. 1-33. [Online]. Available from World Wide Web: http://www-odp.tamu.edu/publications/178_SR/VOLUME/ CHAPTERS/SR178_23.PDF.

Hillenbrand, C.-D., Ehrmann, W., 2005. Late Neogene to Quaternary environmental changes in the Antarctic Peninsula region: evidence from drift sediments. Glob. Planet. Change 45, 165-191.

Hillenbrand, C.-D., Fütterer, D.K., Grobe, H., Frederichs, T., 2002. No evidence for a Pleistocene collapse of the West Antarctic Ice Sheet from continental margin sediments recovered in the Amundsen Sea. Geo Mar. Lett. 22, 51-59.

Honjo, S., 2004. Particle export and the biological pump in the Southern Ocean. Antarct. Sci. 16, 501-516.

Hoppema, M., 2004. Weddell Sea turned from source to sink for atmospheric $\mathrm{CO}_{2}$ between pre-industrial time and present. Glob. Planet. Change 40, 219-231.

Imbrie, J., Boyle, E.A., Clemens, S.C., Duffy, A., Howard, W.R., Kukla, G., Kutzbach, J., Martinson, D.G., McIntyre, A., Mix, A.C., Molfino, B., Morley, J.J., Peterson, L.C., Pisias, N.G., Prell, W.L., Raymo, M.E., Shackleton, N.J., Toggweiler, J.R., 1992. On the 
structure and origin of major glaciation cycles. I. Linear responses to Milankovitch forcing. Paleoceanography 7, 701-738.

Iwai, M., Acton, G.D., Lazarus, D., Osterman, L.E., Williams, T., 2002. Magnetobiochronologic synthesis of ODP Leg 178 rise sediments from the Pacific sector of the Southern Ocean: Sites 1095, 1096, and 1101. In: Barker, P.F., Camerlenghi, A., Acton, G.D., Ramsay, A.T.S. (Eds.), Proc. ODP Sci. Results, vol. 178. Ocean Drilling Program, College Station, TX, pp. 1-40. [Online]. Available from World Wide Web:http://www-odp.tamu.edu/publications/178_SR/ VOLUME/CHAPTERS/SR178_36.PDF.

Jaccard, S.L., Haug, G.H., Sigman, D.M., Pedersen, T.F., Thierstein, H.R., Röhl, U., 2005a. Glacial/Interglacial changes in Subarctic North Pacific stratification. Science 308, 1003-1006.

Jaccard, S.L., Haug, G.H., Sigman, D.M., Pedersen, T.F., Thierstein, H.R., Röhl, U., 2005b. Glacial/Interglacial changes in Subarctic North Pacific stratification - supporting online material. Available from www.sciencemag.org/cgi/content/full/308/5724/ 1003/DC1.

Keeling, R.F., Stephens, B.B., 2001. Antarctic sea ice and the control of Pleistocene climate instability. Paleoceanography 16, doi: 10.1029/2000PA000529 112-131 and corrections doi: 10.1029/ 2001PA000648, 330-334.

Keeling, R.F., Visbeck, M., 2001. Antarctic stratification and glacial $\mathrm{CO}_{2}$ : comment. Nature 412, 605-606.

Kohfeld, K.E., Le Quere, C., Harrison, S.P., Anderson, R.F., 2005. Role of marine biology in glacial-interglacial $\mathrm{CO}_{2}$ cycles. Science 308, 74-78.

Kumar, N., Anderson, R.F., Mortlock, R.F., Froelich, P.N., Kubik, P.W., Dittrich-Hannen, B., Suter, M., 1995. Iron fertilization of glacial age Southern Ocean productivity. Nature 378, 675-680.

Louanchi, F., Hoppema, M., Bakker, D.E.C., Poisson, A., Stoll, M.H.C., De Baar, H.J.W., Schauer, B., Ruiz-Pino, D.P., Wolf-Gladrow, D., 1999. Modelled and observed sea surface $f \mathrm{CO}_{2}$ in the Southern Ocean: a comparative study. Tellus 51B, 541-559.

Lourey, M.J., Trull, T.W., Sigman, D.W., 2003. Sensitivity of $\delta^{15} \mathrm{~N}$ of nitrate, surface suspended and deep sinking particulate nitrogen to seasonal nitrate depletion in the Southern Ocean. Glob. Biogeochem. Cycles 17, 1081, doi:10.1029/2002GB001973.

Maslin, M.A., Haug, G.H., Sarnthein, M., Tiedemann, R., 1996. The progressive intensification of Northern Hemisphere glaciation as seen from the North Pacific. Int. J. Earth Sci. 85, 452-465.

Moore, J.K., Abbott, M.R., Richman, J.G., Nelson, D.M., 2000. The Southern Ocean at the last glacial maximum: a strong sink for atmospheric carbon dioxide. Glob. Biogeochem. Cycles 14, 455-475.

Morales Maqueda, M.A., Rahmstorf, S., 2002. Did Antarctic sea-ice expansion cause glacial $\mathrm{CO}_{2}$ decline? Geophys. Res. Ser. 29, doi:10.1029/2001GL013240.

Nürnberg, C.C., Bohrmann, G., Schlüter, M., Frank, M., 1997. Barium accumulation in the Atlantic sector of the Southern Ocean: results from 190.000-year records. Paleoceanography 12, 594-603.

Pondaven, P., Ragueneau, O., Tréguer, P., Hauvespre, A., Dezileau, L., Reyss, J.L., 2000. Resolving the "opal paradox" in the Southern Ocean. Nature 405, 168-172.
Robinson, R.S., Brunelle, B.G., Sigman, D.M., 2004. Revisiting nutrient utilization in the glacial Antarctic: evidence from a new method for diatom-bound $\mathrm{N}$ isotopic analysis. Paleoceanography 19, PA3001, doi:10.1029/2003PA000996.

Robinson, R.S., Sigman, D.M., DiFiore, P.J., Rohde, M.M., Mashiotta, T.A., Lea, D.W., 2005. Diatom-bound ${ }^{15} \mathrm{~N} /{ }^{14} \mathrm{~N}$ : new support for enhanced nutrient consumption in the ice age subantarctic. Paleoceanography 20, PA3003, doi:10.1029/2004PA001114.

Schneider-Mor, A., Yam, R., Bianchi, C., Kunz-Pirrung, M. Gersonde, R., Shemesh, A., 2005. Diatom stable isotopes, sea ice presence and sea surface temperature records of the past $640 \mathrm{ka}$ in the Atlantic sector of the Southern Ocean. Geophys. Res. Lett. 32, L10704, doi:10.1029/2005GL022543.

Sigman, D.M., Boyle, E.A., 2000. Glacial/interglacial variations in atmospheric carbon dioxide. Nature 407, 859-869.

Sigman, D.M., Boyle, E.A., 2001. Antarctic stratification and glacial $\mathrm{CO}_{2}$ : reply. Nature 412, 606

Sigman, D.M., Jaccard, S.L., Haug, G.H., 2004. Polar ocean stratification in a cold climate. Nature 428, 59-63.

Sigman, D.M., Altabet, M.A., Francois, R., McCorkle, D.C., Gaillard, J.-F., 1999. The isotopic composition of diatom-bound nitrogen in Southern Ocean sediments. Paleoceanography 14, 118-134.

Stephens, B.B., Keeling, R.F., 2000. The influence of Antarctic sea ice on glacial-interglacial $\mathrm{CO}_{2}$ variations. Nature 404, 171-174.

Swann, G.E.A., Maslin, M.A., Leng, M.J., Sloane, H.J., Haug, G.H., 2006. Diatom $\delta^{18} \mathrm{O}$ evidence for the development of the modern halocline system in the subarctic northwest Pacific at the onset of major Northern Hemisphere glaciation. Paleoceanography 21, PA1009, doi:10.1029/2005PA001147.

Takahashi, T., Sutherland, S.C., Sweeney, C., Poisson, A., Metzl, N., Tilbrook, B., Bates, N., Wanninkhof, R., Feely, R.A., Sabine, C., Olafsson, J., Nojiri, Y., 2002. Global sea-air $\mathrm{CO}_{2}$ flux based on climatological surface ocean $\mathrm{pCO}_{2}$, and seasonal biological and temperature effects. Deep-Sea Res. II 49, 1601-1622.

Volpi, V., Camerlenghi, A., Moerz, T., Corubolo, P., Rebesco, M., Tinivella, U., 2001. Data Report: Physical properties relevant to seismic stratigraphic studies, continental rise sites 1095, 1096, and 1101, ODP Leg 178, Antarctic Peninsula. In: Barker, P.F., Camerlenghi, A., Acton, G.D., Ramsay, A.T.S. (Eds.), Proc. ODP Sci. Results, vol. 178. Ocean Drilling Program, College Station, TX, pp. 1-36. [Online]. Available from World Wide Web: http://www-odp.tamu.edu/publications/178_SR/VOLUME/ CHAPTERS/SR178_17.PDF.

Whitehead, J.M., Bohaty, S.M., 2003. Pliocene summer sea surface temperature reconstruction using silicoflagellates from Southern Ocean ODP Site 1165. Paleoceanography 18, 1075, doi:10.1029/ 2002PA000829.

Whitehead, J.M., Wotherspoon, S., Bohaty, S.M., 2005. Minimal Antarctic sea ice during the Pliocene. Geology 33, 137-140, doi:10.1130/G21013.1.

Wolff, E.W., Fischer, H., Fundel, F., et al., 2006. Southern Ocean seaice extent, productivity and iron flux over the past eight glacial cycles. Nature 440, 491-496, doi:10.1038/nature04614. 